\title{
Ketidakpuasan tubuh dan internalisasi media pada remaja
}

\begin{tabular}{l} 
Paramita Hartati ${ }^{*}$ Anita \\
I,2 Universitas Kristen Krica \\
\hline Info Artikel \\
\hline Sejarah Artikel: \\
Diterima \\
08 Juni 2020 \\
Direview \\
19 Oktober 2020 \\
Disetujui \\
07 November 2020 \\
Dipublikasikan \\
I5 Januari 202 I \\
\hline Keywords: \\
Body dissatisfaction, \\
media internalization, \\
adolescents, \\
ideal and actual bodies,
\end{tabular}

Paramita Hartati , Anita Novianty ${ }^{2}$

1,2Universitas Kristen Krida Wacana, Indonesia

\begin{abstract}
Abstrak
Objektif: Pesan yang disampaikan oleh media mengenai bentuk tubuh kurus dan atletis yang dianggap sebagai tubuh ideal dan dijadikan sebagai prinsip penampilan dapat meningkatkan ketidakpuasan terhadap tubuh pada remaja. Ketidakpuasan tubuh merupakan perasaan dan pikiran negatif seseorang terhadap bentuk dan ukuran tubuhnya yang banyak dialami oleh remaja perempuan serta berdampak negatif (kecemasan dan depresi). Oleh karena itu, penelitian ini bertujuan untuk melihat hubungan antara ketidakpuasan tubuh dengan pesan yang disampaikan oleh media pada remaja.
\end{abstract}

Metode: Merupakan penelitian korelasional dengan pendekatan kuantitatif dengan menggunakan Body Dissatisfaction Scale dan Sociocultural Attitudes Towards Appearance Scale-3 sebagai instrumen alat ukur. Partisipan penelitian merupakan kelompok remaja dengan jumlah partisipan I 88 orang (43 laki-laki, I 45 perempuan) dengan rentang usia 18-24 tahun.

Temuan: Terdapat hubungan yang positif dan signifikan antara ketidakpuasan tubuh dengan internalisasi media.

Kesimpulan: Dapat menjadi acuan dalam membentuk program prevensi terhadap ketidakpuasan tubuh dengan merefleksikan diri dan membuka sudut pandang baru mengenai hal positif yang dimiliki oleh orang dengan berbagai bentuk tubuh, serta menyediakan konten, iklan dan sampul produk yang memberikan makna positif terhadap berbagai bentuk tubuh.

\section{Body dissatisfaction and media internalization in adolescents}

Objectives: The message conveyed by the media about thin body shape and athleticism which is considered an ideal body and used as the principle of appearance can increase dissatisfaction with the body in adolescents. Body dissatisfaction is a person's negative feelings and thoughts about their body shape and size which are experienced by many girls and cause negative effects (anxiety and depression). Therefore, this study aims to look at the relationship between body dissatisfaction with the message conveyed by the media to adolescents.

Method: This study is a correlational research type that uses a quantitative approach using the Body Dissatisfaction Scale and the Sociocultural Attitudes Towards Appearance Scale-3 as measuring instruments. The participants of this study were a group of adolescents with 188 participants (43 men, 145 women), aged I8-24 years.

Findings: There is a positive and significant relationship between body dissatisfaction with media internalization.

Conclusions: This research can be a reference in forming a prevention program for body dissatisfaction by reflecting on themselves and opening new perspectives on positive things possessed by people with various body shapes, as well as providing contents, advertisements, and product covers that give positive meaning to various body shapes.

*Alamat korespondensi:

Universitas Kristen Krida Wacana I, Kecamatan Grogol Petamburan, Jakarta Barat, DKI Jakarta, I I 470

phartati98@gmail.com 


\section{Pendahuluan}

Ketidakpuasan terhadap tubuh menjadi permasalahan yang banyak dialami oleh remaja saat ini. Remaja perempuan sebanyak 48,1\% dan remaja laki-laki sebanyak 44,I\% di Malaysia dengan rentang usia 18-25 tahun mengalami ketidakpuasan terhadap tubuhnya dan mengin ginkan bentuk tubuh yang lebih kurus dan berotot dari bentuk dan ukuran tubuhnya saat ini (Kamaria, Vikram \& Ayiesah, 2016). Ketidakpuasan tubuh merupakan keadaan yang berbeda antara keadaan ideal dengan keadaan yang sebenarnya (Melching, Green, O'neal \& Renfroe, 20 I6; Grogran2008). Hal ini dikarenakan karakteristik tubuh ideal dinilai memberikan makna cantik dan menjadi sebuah standar sosial (Martin, 20I0).

Individu dapat memiliki bentuk tubuh ideal karena adanya internalisasi yang dilakukan oleh seseorang. Internalisasi merupakan sebuah proses kognitif di mana individu menerima dan menjadikan nilai masyarakat terkait tubuh ideal ke dalam prinsip penampilannya (Hoffmann \& Warschburger, 2019; Thompson et al., 2004; Blowers et al., 2003; Thompson \& Stice, 200I). Konteks internalisasi yang dimaksud menjadikan nilai tubuh kurus dan berotot sebagai tubuh ideal. Selanjutnya, ketika individu tidak dapat mencapai tubuh ideal yang diinginkannya, maka individu akan mengalami kecemasan dan dapat mengalami peningkatan ketidakpuasan terhadap tubuhnya (Chang et al,. 20/3). Hal ini juga dapat terjadi karena adanya peran media yang memberikan tekanan untuk memiliki tubuh ideal yang kurus dan berotot (Blowers, Loxton, Flesser, Occhipinti \& Dawe, 2003).

Media memberikan pengaruh besar dalam memaparkan bentuk tubuh ideal. Hal ini dikarenakan kemudahan akses internet membuat seseorang dapat dengan cepat menemukan berbagai bentuk tubuh ideal. Berdasarkan hasil survey oleh situs We Are Social-Hootsuite tahun 2018 lalu, sekitar $56 \%$ atau setara dengan 150 juta orang dari total populasi di Indonesia merupakan pengguna internet aktif dengan rata-rata waktu penggunaannya selama delapan jam 36 menit setiap harinya. Platform media sosial yang sering digunakan adalah youtube $(88 \%)$, facebook $(81 \%)$ dan instagram $(80 \%)$. $\mathrm{Hal}$ ini menunjukkan bahwa paparan media terkait tubuh ideal secara sengaja maupun tidak sengaja dapat tersampaikan kepada pengguna internet aktif tersebut.

Media memiliki peran dalam memberikan gambaran yang tidak realistis dan tidak mungkin untuk dicapai (Jung \& Lennon, 20I3; Thompson \& Stice, 200I). Pemaparan bentuk tubuh ideal oleh media yang berasal dari TV, majalah dan film secara terus-menerus dapat mempengaruhi persepsi kecantikan dan penampilan, serta membuat individu melakukan internalisasi (Mills, Shannon, \& Hogue, 20 I7). Mahasiswi dengan rentang usia 17-22 tahun di Universitas Texas, dipaparkan oleh gambaran tubuh ideal melalui media seperti majalah atau produk dan dihasilkan dapat meningkatkan ketidakpuasan terhadap tubuh mereka (Krones, Stice, Batres, \& Orjada, 2005). Akan tetapi, penelitian terbaru menunjukkan hasil yang berbeda yaitu internalisasi yang berasal dari internet dapat lebih mempengaruhi ketidakpuasan tubuh dibandingkan yang berasal dari media televisi dan majalah (Gezgin \& Dev, 20l8).

Hasil penelitian sebelumnya hanya berfokus pada media televisi dan majalah, sedangkan saat ini sudah mengalami perkembangan media yang cukup pesat. Selain itu, sampel penelitian yang berfokus pada remaja perempuan. Hal ini yang membuat peneliti ingin mengetahui hubungan antara ketidakpuasan tubuh dengan internalisasi media pada remaja laki-laki dan perempuan dengan menambahkan media sosial sebagai sumber dari internalisasi media dan melakukan generalisasi pada sampel penelitian.

Penelitian ini diharapkan dapat memberikan sumbangsih pada penelitian terkait topik citra tubuh remaja di bidang psikologi kesehatan. Penelitian ini juga diharapkan dapat memberikan pemahaman kepada remaja mengenai keterkaitan media terhadap ketidakpuasan tubuh dan dapat menjadi acuan dalam membentuk program prevensi terhadap ketidakpuasan tubuh, khususnya pada remaja. 
Peneliti menetapkan hipotesis penelitian ini yaitu terdapat hubungan yang signifikan dan positif antara ketidakpuasan tubuh dengan internalisasi media pada remaja.

\section{Metode}

Penelitian ini menggunakan pendekatan kuantitatif dengan jenis penelitian korelasional. Penelitian korelasional merupakan jenis penelitian yang ingin melihat hubungan antar variabel. Penelitian ini menggunakan metode pengumpulan data dalam bentuk kuesioner online yang dibagikan melalui media sosial (Line dan Instagram).

Variabel kriterium pada penelitian ini adalah ketidakpuasan tubuh, yaitu individu yang memiliki kesenjangan antara tubuh aktual dengan tubuh idealnya. Ketidakpuasan tubuh ditentukan menggunakan Skala Ketidakpuasan Tubuh dengan mengurangi skor dari gambar tubuh yang dipilih sebagai tubuh aktual dengan skor dari gambar yang dipilih sebagai tubuh ideal. Hasil skor menunjukkan bahwa semakin besar nilai skor, maka individu semakin tidak puas dengan tubuhnya.

Variabel prediktor pada penelitian ini adalah internalisasi media, yaitu proses kognitif di mana individu menerima informasi dari media terkait tubuh kurus sebagai tubuh ideal dan mengubah perilakunya untuk mendapatkan tubuh ideal yang diinginkannya tersebut. Internalisasi media dapat diukur dari empat dimensi yaitu information, internalization-general, pressure, dan internalizationathlete. Internalisasi media diukur menggunakan alat ukur The Sociocultural Attitudes Towards Appearance Questionnaire-3 (SATAQ-3) yang dilihat berdasarkan jumlah total skor. Hasil skor menunjukkan bahwa semakin tinggi skor, maka semakin besar internalisasi medianya.

Partisipan dalam penelitian ini merupakan kelompok remaja dengan jenis kelamin laki-laki dan perempuan dengan rentang usia 18-24 tahun. Teknik pengambilan sampel dalam penelitian ini adalah convenience sampling yaitu teknik pengambilan sampel yang bergantung pada kenyamanan peneliti terkait kemudahan akses lokasi atau letak geografis dan kemudahan dalam mendapatkan partisipan penelitian (Kumar, 20I4). Teknik convenience sampling dilakukan dengan mengambil sampel yang sesuai dengan karakteristik partisipan penelitian yang sedang berada di sekitar peneliti.

Skala Ketidakpuasan Tubuh yang dikembangkan oleh Mutale et al. (2016) digunakan untuk mengukur ketidakpuasan terhadap tubuh. Skala ini terdiri dari sembilan urutan gambar tubuh perempuan dan sembilan gambar tubuh laki-laki, yang berturut-turut memiliki berat tubuh yang semakin meningkat, dimulai dari rentang extremely thin sampai obesitas. Skala ketidakpuasan tubuh diuji validitasnya dengan menggunakan validitas isi dengan memberikan instrumen alat ukur kepada tiga ahli. Nilai rasio validitas isi yang diperoleh adalah satu. Reliabilitas skala ini diuji dengan metode test-retest dan diperoleh nilai signifikansi sebesar $0,4 \mathrm{I} \mathrm{I}$.

The Sociocultural Attitudes Towards Appearance Questionnaire-3 (SATAQ-3) yang dikembangkan oleh Thompson, Berg, Roehrig, Guarda, dan Heinberg (2004) digunakan untuk mengukur internalisasi media. Skala Internalisasi Media diuji validitasnya dengan metode corrected item total correlation, dan didapatkan nilai koefisien validitas total skor dengan rentang 0,3 |8-0,730. Reliabilitas skala ini diuji dengan teknik Cronbach Alpha dan diperoleh koefisien reliabilitasnya sebesar 0,920. Butir pernyataan yang valid dan reliabel berjumlah 25 butir pernyataan.

Teknik analisis data yang digunakan adalah teknik analisis korelasional dengan menggunakan Spearman's Correlation Coefficient antara variabel ketidakpuasan tubuh dengan variabel internalisasi media yang akan diukur menggunakan SPSS (Statistical Product and Service Solutions) versi 24. Selain itu, penelitian ini juga mencari BMI partisipan dengan tujuan untuk mengetahui kategori berat badan partisipan apakah sudah proporsional atau belum. 


\section{Hasil}

Partisipan dalam penelitian ini berjumlah 188 orang, dengan jumlah partisipan laki-laki yaitu 43 orang dan jumlah partisipan perempuan yaitu 145 orang. Berdasarkan data partisipan yang diperoleh, dapat disimpulkan bahwa sebagian besar partisipan pada penelitian ini merupakan remaja perempuan, dewasa awal dengan kategori BMI ideal dan obesitas, serta menggunakan media sosial instagram dan melakukan olahraga sebagai kegiatan yang menunjang kesehatannya. Data partisipan penelitian dapat dilihat pada Tabel I.

\section{Tabel I.}

Data Partisipan Penelitian

\begin{tabular}{lll}
\hline \multicolumn{1}{c}{ Kategori } & Jumlah & Persentase (dalam \%) \\
\hline $\begin{array}{lll}\text { Jenis Kelamin } \\
\text { Laki-laki }\end{array}$ & 43 & 22,87 \\
Perempuan & 145 & 77,13 \\
\hline Usia & 11 & \\
I8 & 25 & 5,85 \\
19 & 37 & 13,30 \\
20 & 71 & 19,68 \\
21 & 32 & 37,76 \\
22 & 8 & 17,02 \\
23 & 4 & 4,26 \\
24 & & 2,13 \\
\hline Pengguna Media Sosial & 187 & \\
Ya & 1 & 99,5 \\
Tidak & & 0,5 \\
\hline Kategori BMI & 25 & 13,30 \\
Kurang & 79 & 42,02 \\
Ideal & 26 & 13,83 \\
Berlebih & 58 & 30,85 \\
Obesitas & &
\end{tabular}

Berikut merupakan gambaran partisipan terkait media sosial yang biasanya digunakan.

\section{Gambarl.}

Partisipan terkait Media Sosial

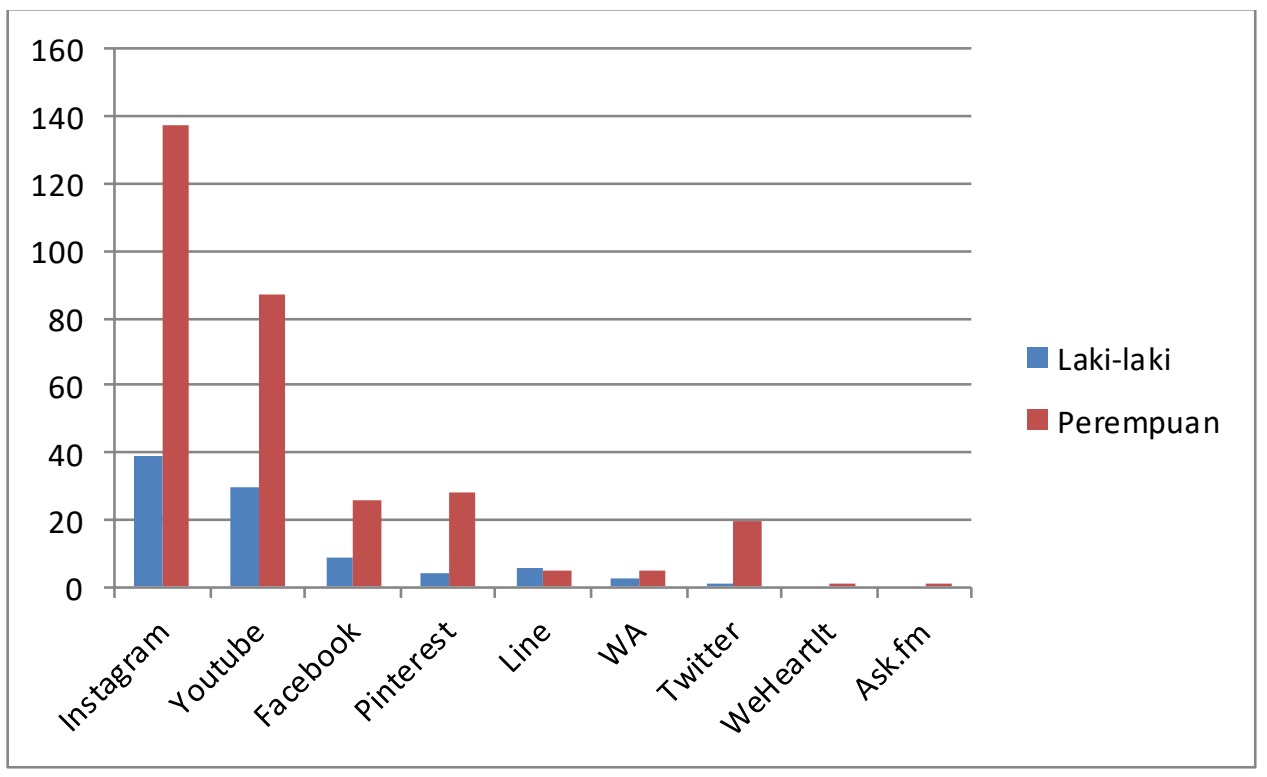


Berikut merupakan persebaran data BMI partisipan laki-laki dan perempuan pada penelitian ini.

\section{Gambar 2.}

Data BMI Partisipan

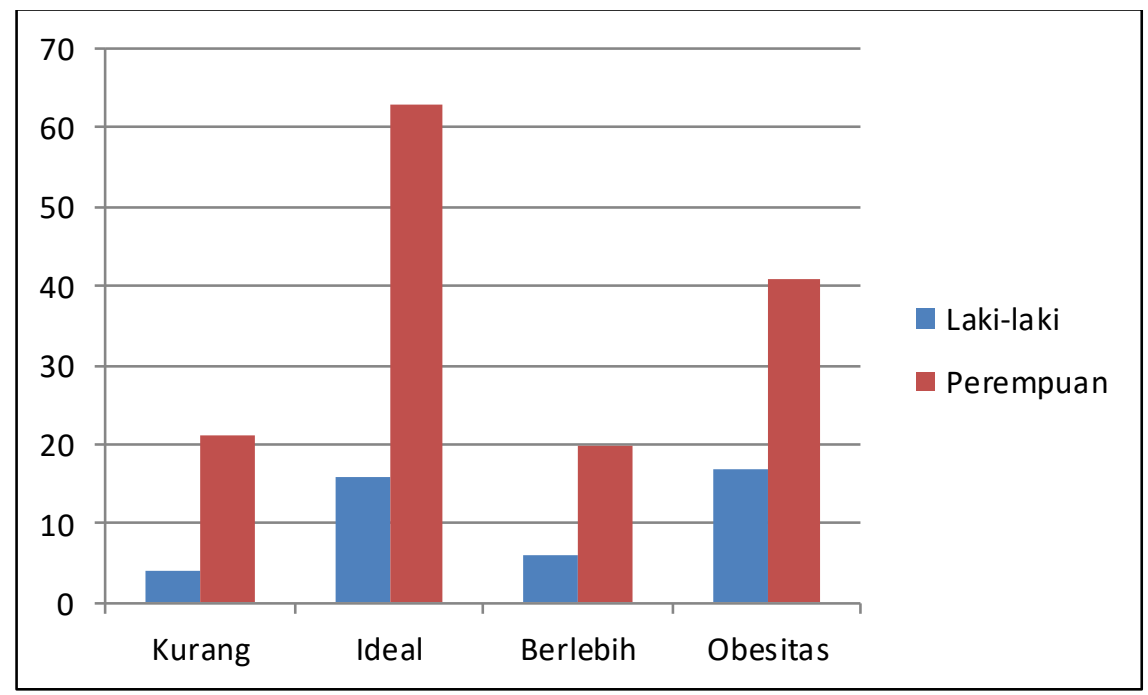

Berikut merupakan persebaran data aktivitas fisik partisipan laki-laki dan perempuan pada penelitian ini yang dibagi ke dalam lima kategori yaitu olahraga, diet, tidak ada, aktivitas fisik, dan tidak teridentifikasi. Aktivitas yang termasuk ke dalam kategori olahraga seperti gym, lari, zumba, futsal, basket dan calisthenics. Aktivitas diet yang dimaksud yaitu menjaga pola makan dan makanmakanan yang sehat. Aktivitas yang termasuk ke dalam kategori aktivitas fisik adalah jalan santai. Kemudian, untuk kategori tidak teridentifikasi diisi oleh aktivitas yang jawabannya tidak sesuai dengan pertanyaan yang diberikan seperti hanya menjawab ya, rebahan atau tidur.

\section{Gambar 3.}

Data Aktivitas Fisik Partisipan

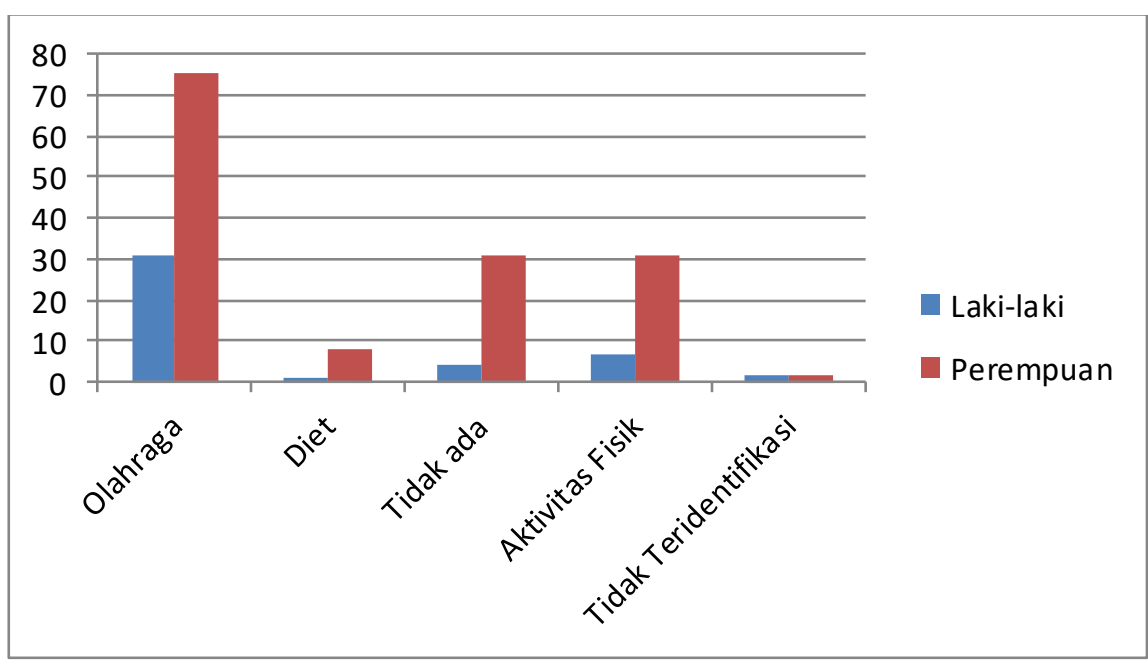

Variabel dalam penelitian ini adalah ketidakpuasan tubuh dan internalisasi media pada remaja. Peneliti mengkategorikan internalisasi media pada remaja secara umum dan berdasarkan perbandingan jenis kelamin laki-laki dan perempuan dengan menggunakan tiga kategori yaitu tinggi, sedang dan rendah. Berdasarkan perhitungan hipotetik dan empirik secara umum, maka didapatkan kategori internalisasi media sebagai berikut: 


\section{Gambar 4.}

Kategori Internalisasi Media

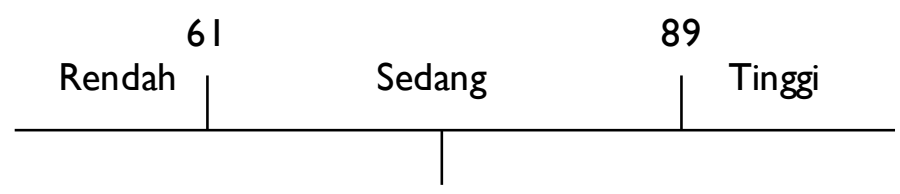

71,07

Tabel 3.

Frekuensi Hasil Pengkategorian Internalisasi Media

\begin{tabular}{cc}
\hline Kategori & Frekuensi \\
\hline Rendah & $5 \mathrm{I}(27 \%)$ \\
Sedang & II $3(60,1 \%)$ \\
Tinggi & $24 \quad(12,8 \%)$ \\
\hline Total & 188
\end{tabular}

Tabel 4.

Hasil Analisa Hipotetik dan Empirik Data Internalisasi Media

\begin{tabular}{lllll}
\hline \multicolumn{5}{c}{ Internalisasi Media } \\
\hline & Mean & $\sigma$ & Min & Max \\
Hipotetik & 75 & 13,67 & 32 & II4 \\
Empirik & 71,07 & 16,480 & 32 & 114 \\
\hline
\end{tabular}

Berdasarkan perhitungan hipotetik dan empirik berdasarkan jenis kelamin, maka didapatkan kategori internalisasi media sebagai berikut.

\section{Gambar 5.}

Kategori Internalisasi Media Remaja Laki-laki

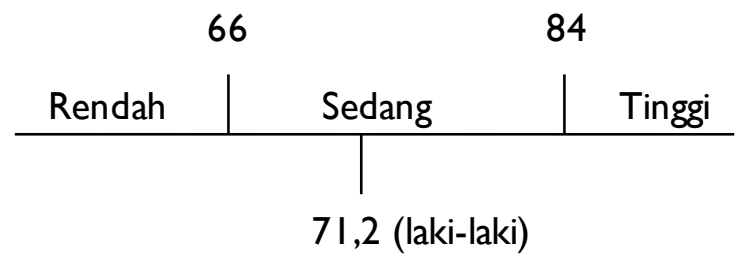

Tabel 5.

Frekuensi Hasil Pengkategorian Internalisasi Media pada Remaja Laki-laki

\begin{tabular}{ll}
\hline \multicolumn{1}{c}{ Kategori } & Frekuensi \\
\hline Rendah & $20(46,51 \%)$ \\
Sedang & $15(34,88 \%)$ \\
Tinggi & $8(18,6 \%)$ \\
\hline Total & 43 \\
\hline
\end{tabular}

Tabel 6.

Hasil Analisa Hipotetik dan Empirik Data Internalisasi Media pada Remaja Laki-laki

\begin{tabular}{lllll}
\hline \multicolumn{5}{c}{ Internalisasi Media } \\
\hline & Mean & $\sigma$ & Min & Max \\
\hline Hipotetik & 75 & 9,33 & 40 & 96 \\
Empirik & 71,2 & 12,95 & 40 & 96 \\
\hline
\end{tabular}




\section{Gambar 6.}

Kategori Internalisasi Media Remaja Perempuan

\begin{tabular}{|c|c|c|}
\hline \multicolumn{2}{|c|}{65} & 35 \\
\hline Rendah & Sedang & Tinggi \\
\hline
\end{tabular}

Tabel 6.

Frekuensi Hasil Pengkategorian Internalisasi Media pada Remaja Perempuan

\begin{tabular}{ll}
\hline \multicolumn{1}{c}{ Kategori } & \multicolumn{1}{c}{ Frekuensi } \\
\hline Rendah & $33(22,76 \%)$ \\
Sedang & $83(57,24 \%)$ \\
Tinggi & $29(20 \%)$ \\
\hline Total & 145 \\
\hline
\end{tabular}

Tabel 7.

Hasil Analisa Hipotetik dan Empirik Data Internalisasi Media pada Remaja Perempuan

\begin{tabular}{lllll}
\hline \multicolumn{5}{c}{ Internalisasi Media } \\
\hline & Mean & $\sigma$ & Min & Max \\
\hline Hipotetik & 75 & 10.17 & 45 & 106 \\
Empirik & 73,61 & 13,094 & 45 & 106 \\
\hline
\end{tabular}

Peneliti melakukan dua uji asumsi yaitu uji normalitas dan uji linearitas. Hasil keduanya dapat digunakan untuk mengetahui teknik korelasi yang akan digunakan untuk menganalisa data penelitian. Uji normalitas dilakukan dengan menggunakan teknik One Sample Kolmogorov-Smirnov untuk melihat apakah data berdistribusi normal. Data dianggap normal jika memiliki nilai koefisien signifikansi lebih dari 0,05 (Azwar, 20I2).

Tabel 8.

Hasil Uji Normalitas Skala Ketidakpuasan Tubuh dan Internalisasi Media

\begin{tabular}{ll}
\multicolumn{1}{c}{ Skala } & \multicolumn{1}{c}{ Signifikansi } \\
\hline Ketidakpuasan Tubuh & 0,00 \\
Internalisasi Media & 0,200 \\
\hline
\end{tabular}

Berdasarkan Tabel 8, variabel ketidakpuasan tubuh tidak berdistribusi normal $(p<0,05)$, namun untuk variabel internalisasi media berdistribusi normal $(p>0,05)$. Oleh sebab itu, uji korelasi yang dilakukan menggunakan teknik Spearman's Correlation Coefficient karena salah satu data tidak berdistribusi dengan normal (Field, 2005).

Peneliti melakukan uji linearitas untuk mengetahui apakah variabel penelitian memiliki hubungan yang linear secara signifikan atau tidak. Uji linearitas dilakukan menggunakan teknik test for linearity. Data dinyatakan memiliki hubungan yang linear jika memiliki nilai koefisien signifikansi deviation from linearity di atas 0,05 . Hasil yang didapat untuk variabel ketidakpuasan tubuh dan internalisasi media memiliki nilai koefisien signifikansi sebesar 0,900 ( $p>0,05)$. Berdasarkan hasil tersebut, dapat disimpulkan bahwa variabel prediktor (internalisasi media) memiliki hubungan yang linear secara signifikan terhadap variabel kriterium (ketidakpuasan tubuh).

Berdasarkan uji hipotesis yang sudah dilakukan, peneliti memperoleh nilai koefisien signifikansi sebesar 0,00I $(p<0,05)$ dan nilai koefisien korelasi sebesar 0,244 $(r<I)$. Hasil tersebut menunjukkan bahwa terdapat hubungan yang signifikan dan positif antara ketidakpuasan tubuh dengan internalisasi media, sehingga disimpulkan bahwa hipotesis diterima. Nilai positif tersebut 
menunjukkan bahwa hubungan kedua variabel bersifat searah, ketika internalisasi media meningkat, maka ketidakpuasan tubuh juga meningkat.

Selain menguji hipotesis, peneliti juga melakukan analisa tambahan dengan menguji korelasi dari masing-masing dimensi internalisasi media dengan ketidakpuasan tubuh dan berdasarkan jenis kelamin. Berdasarkan uji korelasi pada masing-masing dimensi internalisasi media dengan ketidakpuasan tubuh, diperoleh hasil yaitu terdapat hubungan yang signifikan antara dimensi internalization-general dan dimensi pressure dengan ketidakpuasan tubuh. Hal ini dapat dibuktikan dari nilai signifikansi yang diperoleh yaitu di bawah $0,05(p<0,05)$. Selain itu, ditemukan bahwa tidak terdapat hubungan yang signifikan antara dimensi information dan internalization-athlete dengan ketidakpuasan tubuh. Hal ini dapat dijelaskan dari nilai signifikansi yang diperoleh yaitu di atas 0,05 $(p>0,05)$. Hasil uji korelasi antar dimensi internalisasi media dapat dilihat pada Tabel 9.

\section{Tabel 9.}

Korelasi Ketidakpuasan Tubuh dan Dimensi Internalisasi Media

\begin{tabular}{lccll}
\hline Variabel & \multicolumn{4}{c}{ Internalisasi Media } \\
\cline { 2 - 5 } & Information & Int-General & Pressure & Int-Athlete \\
\hline Ketidakpuasan & $\mathrm{r}=0,112$ & $\mathrm{r}=0,228$ & $\mathrm{r}=0,254$ & $\mathrm{r}=0,092$ \\
Tubuh & $\mathrm{P}=0,125$ & $\mathrm{P}=0,002$ & $\mathrm{P}=0,000$ & $\mathrm{P}=0,210$ \\
\hline
\end{tabular}

Hasil uji korelasi masing-masing dimensi internalisasi media dengan ketidakpuasan tubuh yang dibandingkan berdasarkan jenis kelamin, ditemukan bahwa setiap dimensi internalisasi media tidak memiliki korelasi yang signifikan dengan ketidakpuasan tubuh pada laki-laki. Sementara itu, untuk perempuan, dimensi internalization-general, pressure dan internalization-athlete memiliki hubungan dengan ketidakpuasan tubuh. Akan tetapi, diketahui bahwa dimensi information tidak memiliki hubungan yang signifikan dengan ketidakpuasan tubuh pada perempuan. Hasil uji korelasi antar dimensi internalisasi media dengan ketidakpuasan tubuh berdasarkan perbandingan jenis kelamin dapat dilihat pada Tabel 10.

Tabel 10.

Korelasi Ketidakpuasan Tubuh dan Dimensi Internalisasi Media pada Remaja Laki-laki dan Perempuan

\begin{tabular}{llllll}
\hline \multirow{2}{*}{ Variabel } & \multirow{2}{*}{ Jenis Kelamin } & \multicolumn{4}{c}{ Internalisasi Media } \\
\cline { 3 - 6 } & & Information & Int-General & Pressure & Int-Athlete \\
\hline KetidakpuasanT & Laki-laki & $r=0,244$ & $r=-0,074$ & $r=-0,185$ & $r=0,134$ \\
ubuh & & $P=0,115$ & $P=0,636$ & $P=0,236$ & $P=0,391$ \\
& \multirow{2}{*}{ Perempuan } & $r=0,039$ & $r=0,283$ & $r=0,360$ & $r=0,184$ \\
& & $P=0,64 I$ & $P=0,00 I$ & $P=0,000$ & $P=0,027$ \\
\hline
\end{tabular}

Peneliti melakukan perhitungan persentase dari frekuensi gambar tubuh yang dipilih sebagai bentuk tubuh aktual dan ideal partisipan. Bentuk tubuh partisipan remaja laki-laki dan perempuan yang dipilih sebagai bentuk tubuh aktual paling banyak terdapat pada nomor enam (6) dengan masingmasing persentase sebesar $25,6 \%$ dan $26,2 \%$. Selain itu, peneliti juga menghitung persentase dari frekuensi gambar tubuh ideal yang dipilih oleh partisipan. Bentuk tubuh nomor lima (5) paling banyak dipilih sebagai bentuk tubuh yang diinginkan oleh remaja laki-laki sebanyak $62,8 \%$. Bentuk tubuh yang tidak dianggap sebagai bentuk tubuh yang diinginkan terdapat pada bentuk tubuh nomor satu (1), dua (2), tujuh (7), delapan (8), dan sembilan (9). Kemudian untuk perempuan, bentuk tubuh yang paling banyak dipilih sebagai bentuk tubuh yang diinginkan terdapat pada bentuk tubuh nomor empat (4) sebanyak 35,2\%. Hasil tersebut tidak berbeda jauh dengan hasil yang diperoleh pada bentuk tubuh nomor lima (5) yang dianggap sebagai bentuk tubuh id eal yaitu sebanyak $32,4 \%$. Sedangkan, bentuk tubuh yang tidak dianggap sebagai bentuk tubuh yang diinginkan terdapat pada bentuk tubuh nomor delapan (8) dan sembilan (9). Kemudian, perbandingan tubuh aktual dan ideal pada remaja laki-laki dan perempuan dapat dilihat pada Gambar 4 dan Gambar 5. 


\section{Gambar 6.}

Perbandingan Tubuh Aktual dan Tubuh Ideal Remaja Laki-laki

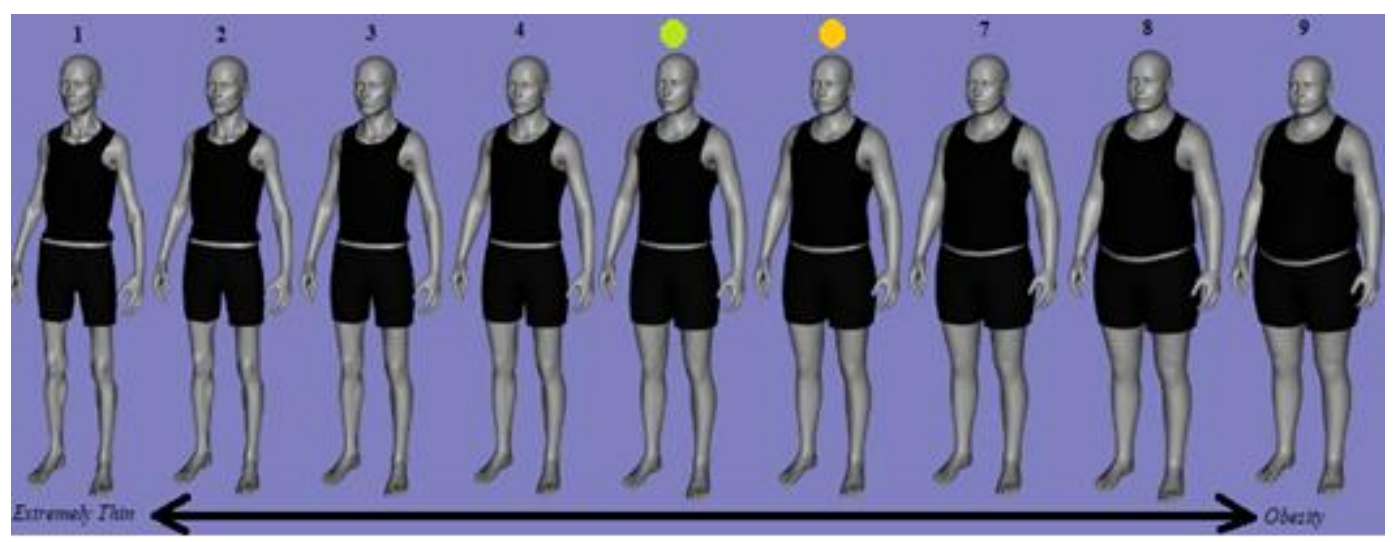

\section{Gambar 7.}

Perbandingan Tubuh Aktual dan Tubuh Ideal Remaja Perempuan

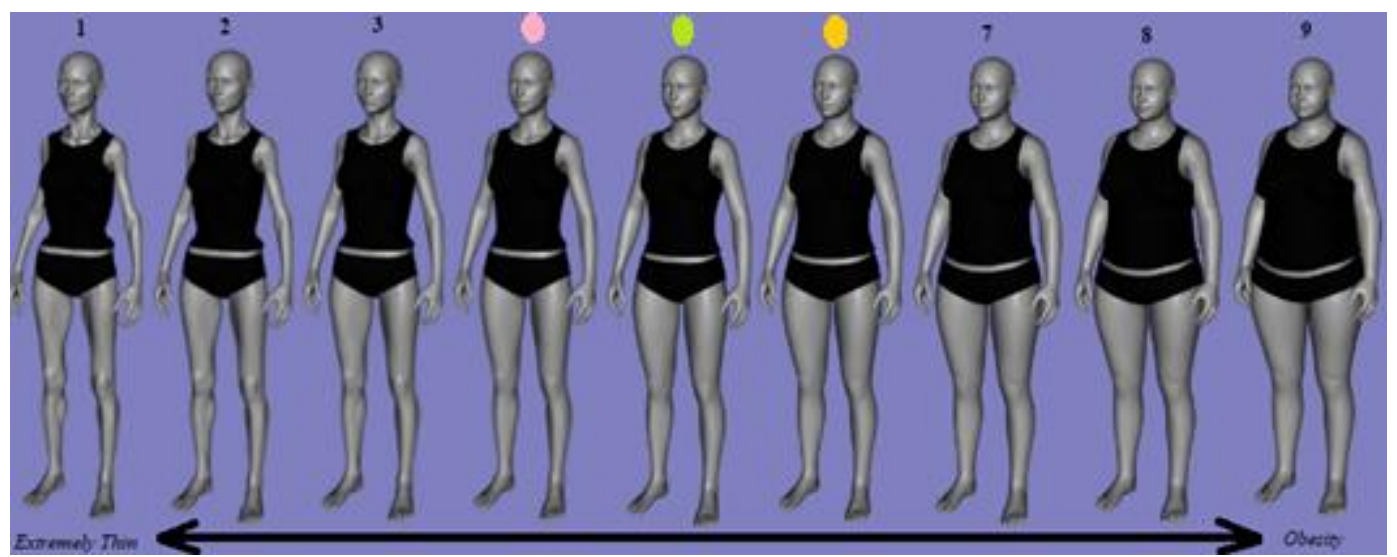

Keterangan:
: Tubuh Aktual
: Tubuh Ideal I
: Tubuh Ideal II

\section{Pembahasan}

Berdasarkan analisa data yang telah dilakukan, ditemukan bahwa semakin tinggi seseorang menerima informasi dari media terkait tubuh ramping dan menginginkan tubuh tersebut, maka semakin tinggi ketidakpuasan terhadap tubuhnya. Hasil penelitian ini menunjukkan bahwa tingkat remaja dalam menerima pesan berada pada kategori sedang, yang berarti remaja rata-rata menerima pesan dari media dan menjadikannya sebagai prinsip penampilannya. Remaja yang memiliki berat tubuh ideal dan obesitas serta dominan menggunakan media sosial instagram terpapar oleh gambaran bentuk tubuh ideal yang ramping dan berotot, serta membuat remaja menginginkan bentuk tubuh ideal tersebut (Griffiths, Murray, Krug, \& McLean, 20 I 8; O'Donnell \& Willoughby, 20I7). Hal ini yang membuat remaja merasa tidak puas dengan bentuk tubuhnya saat ini, sehingga mereka ingin menurunkan berat badan dan menaikkan massa ototnya. Hal ini sejalan dengan penelitian Homan (20l0), bahwa terdapat keterkaitan antara ketidakpuasan tubuh dengan pesan yang disampaikan oleh media pada remaja. 
Berdasarkan perbandingan jenis kelamin antara laki-laki dan perempuan, hasil penelitian ini menunjukkan bahwa perempuan memiliki korelasi antara ketidakpuasan tubuh dengan beberapa komponen yang disampaikan oleh media yaitu keinginan untuk memiliki bentuk tubuh ramping, tubuh atletis dan tekanan sosial (Homan, 20l0). Hal ini menunjukkan bahwa paparan bentuk tubuh ramping dan atletis yang disampaikan oleh media membuat individu merasa tertekan untuk menurunkan berat badan, menaikkan massa otot, ingin terlihat cantik dan memiliki bentuk tubuh sempurna, sehingga dapat meningkatkan ketidakpuasan tubuh (Hoffmann \& Warschburger, 2019; Bennett et al., 2019; Knauss et al., 2007). Penelitian ini didasari oleh kelompok partisipan yang sebagian besar merupakan perempuan dewasa awal yang memiliki kategori indeks massa tubuh ideal, pengguna media sosial instagram, serta berada pada kategori sedang dalam menerima nilainilai yang disampaikan oleh media dan menjadikan prinsip penampilannya.

Gambaran tubuh ideal yang diberikan oleh media kepada remaja perempuan yang merupakan pengguna media sosial instagram dan memiliki berat badan dengan kategori ideal menginginkan bentuk tubuh yang lebih kurus dan atletis dari bentuk tubuhnya saat ini (Hoffmann \& Warschburger, 2019). Hal ini didukung dengan hasil yang didapatkan dari skala ketidakpuasan tubuh, di mana kelompok partisipan perempuan menginginkan bentuk tubuh yang lebih kurus dari bentuk tubuhnya saat ini. Selain itu, hasil penelitian ini sejalan dengan hasil penelitian dari Homan (20I0), bahwa kegiatan yang dilakukan untuk menunjang kesehatan mereka dan mendapatkan tubuh ideal adalah melakukan kegiatan olahraga, seperti gym, skipping, jogging dan zumba, serta menjaga pola makan dengan makan-makanan yang sehat.

Hasil penelitian ini sejalan dengan hasil penelitian Dye (20I5) yang dilakukan di Universitas X pada mahasiswi yang menunjukkan bahwa terdapat korelasi antara ketidakpuasan tubuh dengan pesan yang disampaikan oleh media, di mana semakin tinggi individu menerima pesan yang disampaikan oleh media, maka semakin individu mengalami ketidakpuasan terhadap tubuhnya. Namun jenis media yang digunakan berbeda, di mana pada penelitian sebelumnya masih menggunakan jenis media tradisional seperti majalah, video musik, dan acara TV, sedangkan pada penelitian ini sudah memasukkan jenis media modern seperti media sosial.

Hasil yang berbeda ditemukan pada kelompok remaja laki-laki dengan kategori berat tubuh obesitas dan pengguna media sosial instagram, yaitu tidak terdapat korelasi antara ketidakpuasan tubuh dengan komponen yang disampaikan oleh media. Hal ini berarti pengaruh yang diberikan oleh media dalam segi informasi, paparan bentuk tubuh yang berotot dan atletis, serta tekanan sosial tidak berkaitan dengan ketidakpuasan tubuh pada remaja laki-laki (Van den Berg et al., 2007). Namun, penelitian lainnya menunjukkan bahwa semakin sering menggunakan media sosial, dapat meningkatkan ketidakpuasan tubuh pada remaja laki-laki (de Vries et al., 2016). Aktivitas yang sering dilakukan untuk menunjang kesehatan mereka dengan melakukan olahraga seperti gym, futsal, basket, jogging, workout dan mengatur pola makan dengan baik (diet).

Remaja laki-laki pada penelitian ini memiliki kategori sedang dalam menerima nilai yang disampaikan oleh media dan nilainya lebih rendah dibandingkan kategori sedang yang dimiliki oleh kelompok remaja perempuan. Hal ini dapat menunjukkan bahwa tidak adanya keterkaitan antara ketidakpuasan tubuh dengan komponen pesan yang disampaikan oleh media pada remaja laki-laki karena rendahnya tingkat informasi atau pesan dari media yang diterima dan dijadikan sebagai prinsip penampilannya (Van den Berg et al., 2007). Selain itu, perlu diketahui lebih lanjut mengenai tingkat pemakaian dan konten yang biasanya dilihat saat menggunakan media sosial instagram pada remaja laki-laki dan perempuan, agar dapat mengetahui lebih jelas mengenai banyaknya dan jenis paparan konten yang diterima (Fardouly \& Vartanian, 2016).

Selain itu, temuan penelitian ini adalah remaja laki-laki dan perempuan yang sebagian besar memiliki tubuh ideal dan obesitas menginginkan bentuk tubuh yang lebih kurus dari bentuk tubuhnya saat ini. Diketahui juga bahwa gap tubuh ideal dengan tubuh aktual pada perempuan lebih besar dibandingkan pada laki-laki. Hasil penelitian ini sejalan dengan penelitian yang dilakukan oleh 
Kamaria, Vikram dan Ayiesah (2016) pada remaja berusia I8-25 tahun, di mana remaja perempuan menginginkan bentuk tubuh kurus, namun hasil yang berbeda pada remaja laki-laki yang menginginkan bentuk tubuh yang lebih berat dengan massa otot dari bentuk tubuhnya saat ini.

Berdasarkan hasil penelitian sebelumnya, bahwa remaja laki-laki ingin meningkatkan massa ototnya dibandingkan memiliki bentuk tubuh yang kurus (Kamaria, Vikram \& Ayiesah, 2016). Hal ini mungkin menjadi salah satu alasan tidak ditemukan adanya keterkaitan antara ketidakpuasan tubuh dengan pesan yang disampaikan oleh media pada remaja laki-laki. Hal ini dikarenakan keterbatasan penelitian yang menggunakan skala ketidakpuasan tubuh yang tidak berfokus pada massa otot lakilaki, tetapi berfokus pada bentuk tubuh laki-laki dari rentang tubuh sangat kurus sampai obesitas.

Hasil penelitian ini menambah referensi dan memberikan pemahaman kepada remaja perempuan, terutama dalam konteks di Indonesia mengenai dampak dari pengaruh media terhadap ketidakpuasan tubuh. Semakin tinggi pengaruh media terhadap penampilan diri individu, maka semakin tinggi ketidakpuasan tubuh yang dialami. Hal ini berarti tingginya keterkaitan media dalam membentuk ketidakpuasan tubuh pada remaja perempuan. Oleh karena itu, implikasi dari penelitian ini dapat membentuk program prevensi terhadap ketidakpuasan pada tubuh. Program prevensi dapat dilakukan oleh dua sudut pandang yaitu sebagai konsumen dan penyedia layanan media. Program prevensi yang dapat dilakukan oleh remaja perempuan sebagai salah satu konsumen media adalah perlu merefleksikan diri dan membuka sudut pandang baru mengenai hal positif yang dimiliki oleh orang dengan berbagai bentuk tubuh, sehingga remaja perempuan dapat menerima diri, khususnya dengan bentuk tubuhnya dengan baik. Hal ini dilakukan karena konten yang disediakan media tidak dapat diatur sepenuhnya.

Program prevensi kedua dapat dilakukan oleh pemerintah yang bekerja sama dengan penyedia konten di media dan pengusaha terutama di bidang kecantikan untuk menyediakan konten, iklan dan sampul produk untuk semua usia, khususnya remaja yang memberikan makna positif terhadap berbagai bentuk tubuh.

\section{Kesimpulan}

Penelitian ini menemukan hasil bahwa terdapat hubungan antara ketidakpuasan tubuh dengan pesan yang disampaikan oleh media pada remaja. Hal ini berarti pesan dan paparan gambar bentuk tubuh yang disampaikan oleh media pada remaja, yang kemudian dijadikan sebagai prinsip penampilannya memiliki keterkaitan dengan ketidakpuasan tubuh.

Penelitian ini juga menemukan bahwa pada remaja perempuan terdapat keterkaitan antara ketidakpuasan tubuh dengan beberapa komponen dari pesan yang disampaikan oleh media, seperti informasi, paparan bentuk tubuh kurus dan atletis yang kemudian dijadikan sebagai prinsip penampilan. Hasil yang berbeda ditemukan pada remaja laki-laki, di mana tidak terdapat keterkaitan antara ketidakpuasan tubuh dengan komponen pesan yang disampaikan oleh media.

Hasil penelitian ini juga menemukan bahwa sebagian besar remaja laki-laki dan perempuan dengan tubuh ideal dan obesitas menginginkan bentuk tubuh yang lebih kurus dari bentuk tubuhnya saat ini. Kemudian, ditemukan bahwa remaja perempuan menginginkan bentuk tubuh yang lebih kurus daripada bentuk tubuh yang diinginkan oleh laki-laki.

Hasil penelitian ini menunjukkan bahwa remaja dengan berat tubuh ideal atau pun obesitas yang menerima paparan bentuk tubuh yang disampaikan oleh media dan menjadikannya sebagai prinsip penampilan, memiliki kecenderungan untuk mengalami ketidakpuasan tubuh dengan menginginkan bentuk tubuh yang lebih kurus dari bentuk tubuhnya saat ini. Penelitian ini dapat menjadi acuan dalam membentuk program prevensi terhadap ketidakpuasan tubuh pada remaja.

Secara teoritis, penelitian ini tidak mengukur persepsi bentuk tubuh berotot, massa otot dan berat tubuh yang diinginkan. Hal ini bertujuan untuk mengetahui lebih lanjut mengenai persepsi bentuk 
tubuh berotot seperti apa yang diinginkan oleh partisipan. Selain itu, mengukur massa otot dan berat tubuh yang diinginkan untuk melakukan verifikasi dengan persepsi bentuk tubuh yang diinginkan oleh partisipan. Oleh karena itu, penelitian selanjutnya dapat mengukur persepsi bentuk tubuh berotot, massa otot dan berat tubuh yang diinginkan oleh partisipan.

Secara praktis, penelitian ini menunjukkan bahwa pesan yang disampaikan oleh media memiliki keterkaitan dengan ketidakpuasan tubuh pada remaja perempuan. Oleh karena itu, saran yang dapat diberikan untuk remaja perempuan sebagai salah satu konsumen media, yaitu merefleksikan diri dan membuka sudut pandang baru mengenai hal positif yang dimiliki orang dengan berbagai bentuk tubuh, sehingga remaja perempuan dapat menerima diri, khususnya dengan bentuk tubuhnya dengan baik. Saran yang dapat diberikan untuk pemerintah yaitu melakukan kerja sama dengan penyedia konten dan pengusaha di bidang kecantikan untuk mulai melakukan perubahan dalam membuat sebuah konten, iklan atau sampul sebuah produk dengan memberikan gambaran yang baru pada bentuk tubuh yang lebih berisi kepada masyarakat, dengan harapan masyarakat khususnya remaja dapat meyakini dirinya bahwa tubuh ideal bukan hanya tubuh yang kurus dan atletis.

\section{REFERENSI}

Alebachew, F., \& Ashagrie, M. (2017). The body-image concept analysis of youth and adolescent. American Journal of Biomedical and Life Sciences, 5(6), 130-134. Doi: 10.1 1648/j.ajbls.20170506.14

Alfianto, R. (2019, Mei 17). Survei pengguna internet indonesia: Paling banyak akses konten video. Retrieved November 2019, from JawaPos.com: https://www.google.com/amp/s/www.jawapos.com/oto-dantekno/teknologi/l 7/05/201 9/survei-pengguna-internet-indonesia-paling-banyak-akseskonten-video/\%3famp

Azwar, S. (20I2). Metode penelitian. Yogyakarta: Pustaka Belajar.

Azwar, S. (2016). Metode penelitian (I ed.). Yogyakarta: Pustaka Pelajar.

Bennett, B. L., Whisenhut, B. L., Hudson, D. L., Wagner, A. F., Latner, J. D., Stefano, E. C., et al. (2020). Examining the impact of social media on mood and body dissatisfaction using ecological momentary assessment. Journal of American College Health, 68(5), 502-508. Doi: $10.1080 / 07448481.2019 .1583236$

Blowers , L. C., Loxton, N. J., Grady-Flesser, M., Occhipinti, S., \& Dawe, S. (2003). The relationship between sociocultural pressure to be thin and body dissatisfaction in preadolescent girls. Eating Behaviors, 4(3), 229-244. Doi: 10.1016/SI47I-0I53(03)000I8-7

Bucchianeri, M. M., Arikian, A. J., Hannan, P. J., Eisenberg, M. E., \& Neu mark-Sztainer, D. (20I3). Body dissatisfaction from adolescence to young adulthood: Findings from a 10 -year longitudinal study. Body Image, IO(I), I-7. Doi: I0.10 I6/j.bodyim.20I2.09.00 I

Chang, F.-C., Lee, C.-M., Chen, P.-H., Chiu, C.-H., Pan, Y.-C., \& Huang, T.-F. (20I 3). Association of thin-ideal media exposure, body dissatisfaction and disordered eating behaviors among adolescents in taiwan. Eating Behaviors, I4(3), 382-385. Doi: 10.1 0 I6/j.eatbeh.2013.05.002

Cohen-Swerdlik. (t.thn.). Psychological Testing and Assessment: An Introduction to Tests and Measurement (7th Edition ed.). McGraw-Hill.

Denich, A. U., \& Ifdil. (2015, Juni). Konsep Body Image Remaja Putri. Jurnal Konseling dan Pendidikan, 3(2), 55-6I. Doi: 10.29210/II6500

De Vries, D. A., Peter, J., de Graaf, H., Nikken, P. (2016). Adolescents' social netw ork site use, peer appearance-related feedback, and body dissatisfaction: Testing a mediation model. Journal of Youth and Adolescence, 45, 2 I I -224. Doi: 10.1007/s I0964-0I 5-0266-4

Dye, H. (20I5). Does internalizing society and media messages cause body dis satisfaction, in turn causing disordered eating? Journal of Evidence-Informed Social Work, I3(2), I - I I. doi: I0.1080/2376I 407.20I5.1024572 
Fardouly, J. \& Vartanian, L. R. (2016). Social media and body image concern: Current research and future directions. Social Media and Applications to Health Behavior, 9, I-5. Doi: 10.1016/j.copsyc.2015.09.005

Field, A. (2005). Discovering Statistics Using SPSS. London, Thousand Oaks, New Delhi: SAGE Publications.

Furnham, A., \& Alibhai, N. (1983). Cross-cultural differences in the perception of female body shapes. Psychological Medicine, I3(4), 829-837. Doi: 10.1017/S003329I70005I 540

Gezgin, U. B., \& Dev, V. C. (20।8). Of kate moss \& marilyn monroe: Body dissatisfaction and its relation to media consumption, body mass index and self-esteem in malaysian college women, (22). 190-20I. doi: I0.3I I 23/AKIL.44I973

Griffiths, S., Murray, S. B., Krug, I., \& McLean, S. A. (2018). The contribution of social media to body dissatisfaction, eating disorder symptoms, and anabolic steroid use among sexual minority men. Cyberpsychology, Behavior, and Social Networking, 21. Doi: 10.1089/cyber.2017.0375

Grogan, S. (200I). Body Image: Understanding Body Dissatisfaction in Men, Women and Children. London and New York: Routledge.

Grogan, S. (2008). Body Image: Understanding Body Dissatisfaction in Men, Women and Children (2nd Edition ed.). New York: Routledge/Taylor \& Francis Group.

Hargreaves, D. A., \& Tiggemann, M. (2004). Idealized media images and adolescent body image: "Comparing" boys and girls. Body Image, I (4), 35 I -36I. Doi: I 0.I 0 I6/j.bodyim.2004.10.002

Hoffmann, S., \& Warschburger, P. (2019). Prospective relations among internalization of beauty ideals,body image concerns, and body change behaviors: considering thinness and muscularity. Body Image, 28, 159 - I67. Doi: I0.1016/j.bodyim.2019.01 .01 I

Homan, K. (2010). Athletic-ideal and thin-ideal internalization as prospective predictors of body dissatisfaction, dieting, and compulsive exercise. Body Image, 240 - 245.

Doi: 10.1016/j.bodyim.2010.02.004

Jung, J., \& Lennon, S. (2003). Body image, appearance self-schema, and media images. Family and Consumer Sciences Research Journal, 32(I), 27-5 I. Doi: 10.I I 77/I 077727X03255900

Kamaria, K., Vikram, M., \& Ayiesah , R. (2016). Body image perception, body shape concern and body shape dissatisfaction among undergraduates students. Jurnal Teknologi, 78(6-8), 3742. Doi: 10.1 II I 3/jt.v78.9050

Khor, G. L., Zalilah, M. S., Phan, Y. Y., Ang, M., Maznah, B., \& Norimah, A. K. (2009, April). Perceptions of body image among malaysian male and female adolescents. Singapore Medical Journal, 50(3), 303-3II.

Knauss, C., Paxton, S. J., \& Alsaker, F. D. (2007). Relationship amongst body dissatisfaction, internalisation of the media body ideal and perceived pressure from media in adolescent girls and boys. Body Image, 4(4), 353-360. Doi: 10.1016/j.bodyim.2007.06.007

Krones, P. G., Stice, E., Batres, C., \& Orjada, K. (2005). In vivo social comparison to a thin-ideal peer promotes body dissatisfaction: A randomized experiment. International Journal of Eating Disorder, 38(2), I34- |42. Doi: I0.1002/eat.20 I7 I

Kumar, R. (20|4). Research Methodology: a step-by-step guide for beginners. SAGE Publications. Martin, J. B. (2010). The development of ideal body image perceptions in the united states. Nutrition Today, 45(3), 98-I I 0. Doi: I0.1097/NT.0b0 I 3e3 I8I dec6a2

Mas'ud, H. (20I7). Standar fisik ideal dalam perspektif budaya dan kesehatan (kasus: Obesitas pada etnis bugis). 25-33.

McGuinness, S., \& Taylor , J. E. (2016). Understanding body image dissatisfaction and disordered eating in midlife adults. New Zealand Journal of Psychology, 45(I), 4-I 2.

Melching, K. L., Green, J. M., O'neal, E. K., \& Renfroe, L. (20I6). Body image dissatisfaction: responses between male and female exercisers and non-exercisers. International Journal of Exercise Science, 9(3), 249-257.

Mills, J. S., Shannon, A., \& Hogue, J. (2017). Perception of Beauty. INTECH. 
Monteagudo, C., Dijkstra, S. C., \& Visser, M. (20I4). Self-Perception of body weight status in older dutch adults. The Journal of Nutrition, Health \& Aging, 19(6), I -7. Doi: I0.1 007/s I 2603-0I50486-z

Mutale, G. J., Stiller, J., Dunn, A., \& Larkin, R. (2016). Development of a body dissatisfaction scale assessment tool. The New School Psychology Bulletin, 13(2), 47-57.

O'Donnell, N. H., \& Willoughby, J. F. (20I7). Photo-sharing social media for eHealth: analysing perceived message effectiveness of sexual health information on instagram. Journal of Visual Communication in Medicine, 40, I49 - I 59. Doi: I0.I080/I 7453054.20 I 7.I 384995

Periantalo, J. (2016). Penelitian Kuantitatif Untuk Psikologi. Yogyakarta: Pustaka Pelajar.

Riyanto, A. D. (2019, Februari 9). Hootsuite (We are Social): Indonesian Digital Report 2019. Retrieved November 2019, from andi.link: https:/landi.link/hootsuite-we-are-socialindonesian-digital-report-2019/

Rodgers, R. F., McLean, S. A., \& Paxton, S. J. (20I5). Longitudinal relationship among internalization of the media ideal, peer social comparison, and body dissatisfaction: implications for the tripartite infliuence model. Developmental Psychology, 5 I (5), 706 7/3. doi: $10.1037 / \operatorname{dev} 0000013$

Solistiawati, A., \& Novendawati. (20I5). Hubungan antara citra tubuh dengan harga diri remaja akhir putri (studi pada mahasiswi reguler universitas esa unggul). Jurnal Psikologi, I3(I), 13-20.

Swami, V., Frederick, D. A., Aavik, T., Alcalay, L., Allik, J., Anderson, D., et al. (2010). The attractive female body weight and female body dissatisfaction in 26 countries across 10 world regions: Results of the international body project I. Personality and Social Psychology. Bulletin, 36(3), 309-325. Doi: I0.1 I77/0 I46/67209359702

Thapa, D. K., \& Thapa, S. (20I5). Gender differences in body image dissatisfaction and eating disorder among nepalese adolescents: A paradigm shift from fatness to thinness. iMedPub Journals, I (2), I-5. Doi: I0.2 I 767/247 I -9854.I 000 I 2

Thompson, J. K., \& Stice, E. (200I). Thin-ideal internalization: Mounting evidence for a new risk factor for body-image disturbance and eating pathology. Current Directions in Psychological Science, I0(5), I8I - 183. Doi: I0.I I I I/I467-872 I.00 I44

Thompson, J. K., van den Berg, P., Roehrig, M., Guarda, A. S., \& Heinberg, L. J. (2004). The sociocultural attitudes towards appearance scale-3 (SATAQ-3): Development and validation. International Journal of Eating Disorder, 35(3), 293 - 304. Doi: 10.1002/eat. 10257

Uchoa, F. N., Uchoa , N. M., Daniele, T. M., Lustosa, R. P., Garrido, N. D., Deana, N. F., et al. (2019). Influence of the mass media and body dissatisfaction on the risk in adolescent of developing eating disorders. International Journal of Environmental Research and Public Health, I6(9). Doi: 10.3390/ijerph I609I 508

Van den Berg, P., Paxton, S. J., Keery, H., Wall, M., Guo, J., \& Neumark-Sztainer, D. (2007). Body dissatisfaction and body comparison with media images in males and females. Body Image, 4(3), 257-268. Doi: 10.1016/j.bodyim.2007.04.003 